\title{
Tramando concepções e sentidos para redizer o direito à educação de jovens e adultos
}

\author{
Jane Paiva \\ Universidade do Estado do Rio de Janeiro, Faculdade de Educação
}

Escrever, numa hora daquelas? O que ele explicado mandou, eu fui e principiei; que obedecer é mais fácil do que entender. Era? [...] "Ah, o que eu não entendo, isso é que é capaz de me matar..."

Guimarães Rosa, 1986, p. 287.

A pesquisa empreendida pretendeu desvelar a face atual da área de educação de jovens e adultos, nos movimentos que experiências e práticas vêm realizando e na relação com as proposições políticas que as instâncias oficiais têm assumido. Para esse desvelamento, analisei as concepções dessas experiências e práticas, propondo um entendimento não de supressão de outros entendimentos, mas uma incorporação de perspectivas que pudessem permitir compreender mais amplamente o fenômeno. Procurei ver essas experiências e práticas na complexidade das relações em que ocorrem, levando em conta que sempre estiveram presentes sem serem consideradas, ou tenderam a aparecer diante das transformações que afetam as sociedades e as culturas na economia globalizada.
Riobaldo $^{1}$ anima-me no esforço de sistematizar as concepções da educação de jovens e adultos que se explicitaram em seis projetos investigados com a finalidade de representarem o atual momento em que a educação de jovens e adultos se realiza na sociedade brasileira, buscando seus sentidos, nexos, possibilidades, relações, visando a expressar a complexidade das concepções contemporâneas da área.

Com vista à constituição de meu objeto, lidei com "novos paradigmas [que] questionam um conjunto de premissas e noções que orientaram até hoje a atividade científica, dando lugar a reflexões filosóficas sobre a ação social e sobre a subjetividade", no dizer de Schnitman (1996, p. 16), para quem a base dessas perspectivas se assenta na "exploração que inclui em seu desenvolvimento a consideração do próprio processo de conhecer, do sujeito cognitivo, da rede social na qual este conhecimento está distribuído", ou de outras produções teóricas que,

1 Personagem de Guimarães Rosa em Grande sertão: veredas. 
sem comportarem o arcabouço paradigmático, vêm buscando contribuir para o repensar do que está posto. Entre elas, as noções de pensamento complexo, como proposto por Morin (2001) e de rede, como metáfora para o processo de conhecimento, de que Schnitman (1996), Najmanovich e Dabas (1995) e Alves (1998) se valem.

Para isso, exigi-me o esforço de uma construção metodológica coerente com esse novo paradigma, que me permitisse - e aos meus interlocutores - trabalhar em um tempo de criatividade, de restauração de elementos singulares e da abertura de novas potencialidades.

Entendendo que a questão da educação de jovens e adultos assume a perspectiva de inclusão em sociedades democráticas, e que esta inclusão passa a se dar pela conquista de direitos, tomei como matrizes conceituais direito e democracia, admitindo que são estes os conceitos fundantes da ampliação da compreensão do que é a educação de jovens e adultos, na contemporaneidade.

Meu objeto de pesquisa, assim, à procura de novos "achados" entre as concepções de educação de jovens e adultos, compôs um corpus em que os movimentos da sociedade se revelaram pelas práticas dos últimos anos, alterando os sentidos que lhes são atribuídos originalmente, quando formulados e retratados em documentos e em aparatos jurídicos. Contrapondo formulações do cotidiano a textos legais, experimentei compreender a educação de jovens e adultos a partir de carecimento e necessidade social, essencialmente produzidos na história, que vêm constituir o que se reconhece como direito em resposta a esses carecimento e necessidade, fundamentais ao entendimento teórico, por ser o direito freqüentemente negado e em poucos momentos respeitado, em relação a todos os cidadãos.

$\mathrm{O}$ que apresento neste artigo, portanto, mais do que um trabalho acabado, traduz um conjunto de reflexões de quem percorre um caminho de estudo teórico que ultrapassa os conhecimentos já disponíveis para, crítica e criativamente, ampliá-los.

\section{Como cigana: o percurso teórico-metodológico da pesquisa}

A definição do percurso da pesquisa foi feita internalizando a fala de Morin (2001, p. 27), que me remeteu ao sentimento errante de que muitos de nós somos tomados, quando precisamos definir e fazer escolhas teórico-metodológicas:

[...] há cerca de quarenta anos, estamos diante de um mundo singularmente novo. E temos de nos situar neste mundo, do qual não passamos, evidentemente, de uma minúscula parte. [...] essa parte se encontra num todo gigantesco, o todo se encontra, ao mesmo tempo, no interior dessas parcelas ínfimas que nós somos, [...] Somos os filhos do cosmos e, ao mesmo tempo, como disse Jacques Monod, nele vivemos como "ciganos".

Vagueando como cigana, intentei caminhos, aproximando-me e distanciando-me do todo e da parte, sempre pronta a novas perguntas, embora duas grandes questões tenham orientado a pesquisa, e retomoas, neste momento, para trazê-las como guiões destas reflexões.

Concepções de alfabetização são, ainda, desafio a enfrentar, pela forma como educadores se formaram, crendo que, porque ensinam, os sujeitos aprendem. Quando estes não aprendem, a "culpa", atribuída aos próprios sujeitos, exime professores da responsabilidade. Saberes e conhecimentos produzidos fora da escola têm pouca chance de serem considerados, pois são sistematicamente negados em situação de aprendizado da leitura e da escrita. Então, com essa premissa, formulei a primeira questão: Que concepções de alfabetização e de escolarização fundamentam as propostas curriculares na educação de jovens e adultos e como contribuem para atualizar as concepções próprias do campo da educação de jovens e adultos?

Outras concepções, como a de educação permanente, explorada nos anos de 1970, voltaram à cena nos últimos anos, reconceitualizadas ante a necessidade de pensar desenvolvimento e educação, cidada- 
nia e produção da existência pelo trabalho, conhecimento e cultura, diversidade e unidade. Da recuperação de tempo perdido chegou-se à concepção de $d i$ reito, englobando o saber ler e escrever como condição de busca de igualdade, às concepções de promoção de cidadania, pela tomada de consciência de direitos de várias sortes. Mesmo integrando a concepção provisória que assumi sobre educação de jovens e adultos, a pesquisa não tratou dessas concepções, cabendo-me investigar, entretanto: Com que perspectivas teórico-metodológicas os saberes da prática social passaram a constituir as redes de conhecimento em projetos de educação que visavam ao direito de todos à educação, e que implicação tinham no repensar os sentidos contemporâneos da educação de jovens e adultos?

Para responder essas questões, pus-me a buscar compreender, ao longo de pouco mais de meio século, desde o pós-guerra, concepções e sentidos que conformaram a educação de jovens e adultos na contemporaneidade, produzidos no interior dos países, nas tensões sociais em tentativas de reafirmação de direitos de maiorias - vistas, na sociedade desigual, como minorias. Essa busca exigiu um mergulho na história nacional - memória e práticas - e nos acordos internacionais, traduzindo a educação de direito social a direito humano em 1948, estendido a toda pessoa, nos termos da Declaração Universal dos Direitos Humanos.

Uma compreensão do que significa esse direito se encontra em Bobbio (1992, p. 4): "no plano histórico a afirmação dos direitos do homem deriva de uma radical inversão de perspectiva, característica da formação do Estado moderno, na representação da relação política, ou educação de jovens e adultos na relação Estado/cidadão ou soberano/súditos [...]”. Bobbio vai mais longe, afirmando "[...] que os direitos do homem, por mais fundamentais que sejam, são direitos históricos, ou seja, nascidos em certas circunstâncias, caracterizadas por lutas em defesa de novas liberdades contra velhos poderes, e nascidos de modo gradual, não todos de uma vez e nem de uma vez por todas" (idem, p. 5).
Admitindo também que é impossível pensar o direito sem pensar democracia, tratei os conceitos pelas imbricações estabelecidas entre eles nesse campo, restringindo-me ao movimento de buscar raízes históricas do que se consagrou como direito à educação.

A questão do direito envolve, inelutavelmente, a condição democrática, valor assumido pelas sociedades contemporâneas em processos históricos de luta e conquista da igualdade entre os seres humanos. No campo da educação, o direito e o exercício democrático têm sido permanentes temas em disputa. Especificamente na educação de jovens e adultos, a história não só registra os movimentos de negação e de exclusão que atingem esses sujeitos, mas se produzem a partir de um direito conspurcado muito antes, durante a infância, negada como tempo escolar e como tempo de ser criança a milhões de brasileiros.

Observações empíricas mostram que pais com pequena ou nenhuma escolaridade reivindicam primeiro para seus filhos a condição de direito à educação, diversa da deles próprios, e poucas vezes se incluem como credores do mesmo direito. Quando a perspectiva de direitos constitui demanda, novas relações estabelecem-se com o poder público e o exercício da democracia é praticado nas negociações em defesa de novos direitos, com concepções e expectativas por parte dos poderes tensionados e dos movimentos sociais.

Professores quase sempre formados para lidar com crianças acabam "caindo", no âmbito dos sistemas, em classes de jovens e adultos com pouco ou nenhum apoio ao que deveriam realizar. Também educadores populares, plenos de verdades sob o prestígio da educação popular, descrevem concepções pautadas em um tempo, em uma realidade social cujo movimento se altera, necessariamente, por ser histórico, sem que as enunciações ou mesmo as práticas o acompanhem.

A prática social (re)significa o campo de atuação, exigindo dos pesquisadores outras formulações para compreender e apreender esses sentidos, no âmbito da cultura de suas populações. 
Ora, os nomes são muitos e debaixo deles: educação popular, educação de base, educação de adultos, educação fundamental, educação comunitária, educação permanente, há coisas e intenções iguais, semelhantes e até opostas. Neste emaranhado estão escondidas idéias iguais com rótulos diferentes e idéias diferentes com rótulos iguais. Há projetos e sobretudo há propósitos, muitas vezes opostos, que se cobrem das mesmas falas e, com palavras que pela superfície parecem apontar para um mesmo horizonte, procuram envolver as mesmas pessoas, prometendo a elas mudanças nas suas vidas, ou em seus mundos. (Brandão, 1984, p. 15)

Brandão revelou-me a profusão dos nomes que não são inocentes, mas trazem imbricados sentidos e significados de fortes marcas ideológicas, orientadoras dos caminhos e das escolhas dos projetos educativos/ educacionais. Porque com ele compartilhava a mesma preocupação, vivenciando também em minha prática essa "confusão", assumi explicitar uma concepção provisória sobre educação de jovens e adultos para, ao longo do estudo, questioná-la e com ela dialogar à exaustão, com a finalidade de favorecer a compreensão de inevitáveis mudanças de concepção na educação de jovens e adultos, historicamente guiada pela perspectiva do direito.

Pós-Hamburgo (1997), ${ }^{2}$ duas importantes vertentes consolidaram a educação de jovens e adultos: a primeira, a da escolarização, assegurando o direito à educação básica a todos, independentemente da idade, e considerando a educação como direito humano fundamental; a segunda, a da educação continuada, como exigência do aprender por toda a vida, independentemente da educação formal e do nível de escolaridade, o que inclui ações educativas de gênero, de etnia, de profissionalização, questões ambientais

2 Referência à cidade alemã em que se realizou a V Conferência Internacional de Educação de Adultos (CONFINTEA), quando países-membro da Organização das Nações Unidas (ONU) firmaram novos acordos para a área, por meio da Declaração de Hamburgo e da Agenda para o Futuro, em julho de 1997. etc., assim como a formação continuada de educadores, estes também jovens e adultos em processos de aprendizagem. A segunda vertente, verdadeiro sentido da educação de jovens e adultos, ressignifica processos de aprendizagem pelos quais os sujeitos se produzem e se humanizam, ao longo de toda a vida, e não se restringe à questão da escolarização, e muito menos da alfabetização.

Da visão ainda muito corrente de que a educação de jovens e adultos se faz para recuperar o tempo perdido daqueles que não aprenderam a ler e a escrever; passando pelo resgate da dívida social, até chegar à concepção de direito à educação para todos e do aprender por toda a vida, as enunciações variaram, deixando no imaginário social a sua marca mais forte, ligada à volta à escola, para fazer, no tempo presente, o que não foi feito no tempo da infância e da adolescência.

Para além da alfabetização, o sentido cada vez se afastou mais, nas políticas públicas, das conquistas e do reconhecimento do valor da educação como base ao desenvolvimento humano, social e solidário. Mais do que alfabetização, o direito constitucional de ensino fundamental para todos sintetizou o mínimo a que se chegara: o de aprender a ler e a escrever com autonomia. Isso significa ter domínio suficiente para, em processo de aprendizado continuado, se manter em condições de acompanhar a velocidade e a complexidade do mundo contemporâneo, que exige aprender continuadamente, por toda a vida, ante os avanços do conhecimento e a permanente criação de códigos, linguagens, símbolos e de sua recriação diária. E exige, para isso, não só o domínio da linguagem escrita, mas também competência como leitor e escritor de seu próprio texto, de sua história, de sua passagem pelo mundo. Exige, ainda, reinventar os modos de sobreviver, transformando o mundo.

Mas não são as concepções e sim especialmente as práticas que definem a educação de jovens e adultos, na vertente da escolarização. Por muito tempo, e até hoje, continuam compreendidas no âmbito do atendimento aos que não sabem ler e escrever, privados da rede de conhecimentos que se produz, se organiza, 
se dissemina, se socializa por meio da escrita, sem que o acúmulo de experiências se associe a sucesso, na luta "contra o analfabetismo".

A definição dos critérios de seleção dos projetos a serem estudados levava em conta a necessidade de que a pesquisa tivesse abrangência nacional, diante do fato de que deveria tomar referências mais amplas para empreender o estudo proposto: compreender as concepções da educação de jovens e adultos, por entender que concepções, porque históricas, têm temporalidade e espacialidade, são multidimensionais, organizando-se segundo diversas ordens de fatores que não permanecem duradouramente, mas são sensíveis aos movimentos dos sujeitos nas suas ações de fazer e desfazer, pensar e transformar o mundo.

Os critérios construídos foram considerados isoladamente ou cruzados um com outro, reforçando-se ou intensificando-se, e decidindo a escolha dos projetos/programas:

a) Abrangência nacional -independentemente da proposta/concepção, a prática deveria realizarse em vários estados da federação, por um ou mais organismos, envolvendo largo número de sujeitos, o que quase sempre contraria as lógicas da educação de jovens e adultos, de pequenas experiências localizadas. Projetos selecionados: Programa Alfabetização Solidária; Programa SESI Educação do Trabalhador - SESIeduca; Programa SESC Ler.

b) Antiguidade e permanência da organização na rede pública - independentemente da concepção, o fato de estar institucionalizada, ininterruptamente, como modalidade de atendimento, no sistema de ensino. Projetos selecionados: Programa de Educação de Jovens e Adultos, da Secretaria Municipal de Educação do Rio de Janeiro; Programa de Educação de Jovens e Adultos, do estado da Bahia.

c) Necessidade de oferecer resposta específica, considerando a realidade de uma dada região ou de determinados sujeitos - verificar a con- sistência de propostas que se orientavam pela ação de educação de jovens e adultos com formato próprio, considerando a especificidade de uma região. Projetos selecionados: Sempre é tempo de aprender/Programa Nacional de Educação na Reforma Agrária (PRONERA), desenvolvido pelo MST (Movimento dos Trabalhadores Rurais Sem Terra); Programa SESC Ler.

A escolha desses programas/projetos não se colocou com nenhuma superioridade sobre qualquer outra, destacando que muitos deles tinham estatura para enfrentar estudos que lhes capturassem concepções e sentidos. As circunstâncias e o acesso aos escolhidos definiram-nos como integrantes do corpus da pesquisa, recomendando-se, entretanto, futuras investigações sobre outras construções no campo da educação de jovens e adultos.

Intensificando o olhar sobre os critérios, e buscando ver em relação, no dizer de Soares (2005, p. 173), procurei garantir relevância ao recorte tomado como objeto de estudo e compreensão da realidade, de modo que fosse possível estabelecer algumas enunciações conceituais sobre o campo, e que o conhecimento produzido também se orientasse para a surpresa e a partilha (Nicolescu, 2003, p. 46), diferentemente do saber do conhecimento disciplinar, orientado para o poder e a posse.

A surpresa, sempre bem-vinda e necessária, deveria levar-me, como conhecedora do campo, a novos estranhamentos, capazes de objetivar a compreensão do mundo presente, no movimento, na dinâmica gerada pela ação dos vários níveis de realidade ${ }^{3}$ ao

3 Nicolescu (2003, p. 46-47) parte da idéia inicial de que Realidade (com R maiúsculo) é tudo aquilo que resiste às nossas experiências, representações, descrições, imagens ou formalizações matemáticas, porque o real, por definição, está oculto para sempre (aquilo que é). Por nível de Realidade, diz o autor, “deve-se entender um conjunto de sistemas invariante à ação de um certo número de leis gerais: por exemplo, as entidades quânticas subor- 
mesmo tempo, onde poderia apreender os objetos, realizando também movimentos que possibilitassem percebê-los nas múltiplas relações em que ocorrem, e não referidos como fragmentos de um mesmo e único nível de realidade (idem, p. 44).

Para Nicolescu (idem, p. 46), ainda, o conhecimento produzido por meio da abordagem transdisciplinar gera a compreensão, enquanto a abordagem disciplinar produz o saber; na primeira abordagem há um novo tipo de inteligência, que implica o equilíbrio entre o mental, os sentimentos e o corpo, incluindo-se os valores, e atuando-se com a lógica do terceiro incluído; na disciplinar a inteligência é analítica, a lógica é binária e há exclusão dos valores. Pela abordagem transdisciplinar, há uma evolução do conhecimento, ou seja, o conhecimento permanece aberto para sempre.

A metodologia requeria, dessa forma, o estudo prévio das origens e dos sentidos que o direito à educação assumia na história, como fundamento para melhor apreender as proposições de programas/projetos e suas formulações conceituais, assim como a compreensão de práticas desenvolvidas, quando possível, pela voz de coordenadores, de dirigentes, de professores/educadores confrontando-as quanto ao pensar (dos especialistas que formulam) e o fazer cotidiano dos sujeitos que coordenavam, dirigiam, rea-

dinadas às leis quânticas, que divergem radicalmente das leis do mundo macrofísico. Isso quer dizer que dois níveis de realidade são diferentes se, ao passar de um para o outro, houver ruptura das leis e ruptura dos conceitos fundamentais (por exemplo, da causalidade)". A visão transdisciplinar parte dos questionamentos de Edmund Husserl e de outros pesquisadores sobre os fundamentos da ciência, descobrindo a existência de diferentes níveis de percepção da Realidade pelo sujeito-observador, o que já fora afirmado por diferentes tradições e civilizações, mas baseada em dogmas religiosos ou em explorações do universo interior. Essa forma de visão propõe "considerar uma Realidade multidimensional, estruturada em múltiplos níveis, que substituiria a Realidade unidimensional, num único nível, do pensamento clássico" (idem, p. 48). lizavam essas propostas. Porque propostas não definem, necessariamente, seus fazeres, suas práticas, busquei a perspectiva metodológica da experiência, em maior aproximação com os quefazeres de algumas delas, no intuito de poder compreender as apreensões dos sujeitos que as desenvolviam, na expressão de suas concepções, nos contextos socioculturais em que se davam, atenta a:

a) constituintes e determinantes da concepção de educação de jovens e adultos e de alfabetização expressos nos discursos e nos documentos;

b) concepções submersas, fazendo-as emergir, a partir dos instrumentos conceituais e das ferramentas que organizavam as próprias situações de aprendizagem.

Os modos como cada programa/projeto foi abordado estiveram condicionados também a fatores de ordem conjuntural, que tanto favoreceram a construção da abordagem, quanto a restringiram. De todos os programas/projetos, no entanto, os documentos básicos estiveram sob o foco da pesquisadora, sem exceções, limitados apenas pela quantidade de textos sistematizados e pela disponibilização que cada instituição fez deles.

As práticas, no entanto, não atenderam aos mesmos modos de abordagem, pelas distâncias, previsíveis para uma pesquisa de abrangência nacional. Uma variedade de métodos de abordagem, com vistas a captar os diversos níveis de realidade, possibilitou a escuta e a apreensão dessas práticas, por meio dos discursos de participantes dos programas/projetos, de variados níveis institucionais.

Desde o início, orientei a construção metodológica do projeto pela noção de redes e de complexida$d e$, procurando tecer um modo de apreender não apenas as expressões conceptuais dos projetos e práticas, mas as teias que se formavam entre eles, relacionadas às diversas dimensões da vida sociopolítica em que se davam/eram possíveis, sem que meu próprio juízo crítico estivesse seguro do percurso intentado. 
Havia um desafio: aproximar as enunciações e compreensões sobre redes à complexidade e às formulações da transdisciplinaridade, que percebia muito próximas do que as redes vinham apontando. Por ser esse um campo novo para transitar, empreendi, mais uma vez como cigana, a aventura de tentar dialogar com essas concepções, em torno do meu objeto, compreendendo-o, não pela análise, mas pela busca de um outro modo de conhecer, que intentei produzir como metodologia de pesquisa.

Autores nacionais encabeçam a discussão sobre redes de conhecimentos, valendo-se para isso de estudos empreendidos por pesquisadores de diversas áreas, em busca de modelos explicativos mais adequados ao lugar epistemológico do conhecimento na contemporaneidade. Morin é um desses pensadores, junto a Prigogine, Maturana, Nicolescu. Alves (2002, p. 113), por exemplo, assinala que é em rede - rede de relações entre sujeitos - que se tecem os saberes e as subjetividades que formam esses sujeitos. Contrapõe-se à grafia em árvore - forma de representar e organizar linear e hierarquizadamente o conhecimento em nossa sociedade -, que valoriza a chamada "teoria", em detrimento da "prática" dos sujeitos, produzida nas mais diversas instâncias sociais.

Conquistas e avanços a esse modo de pensar e conceber o conhecimento, no entanto, só são possíveis a partir de um movimento histórico que contribuiu com as teorias crítico-reprodutivistas, construtivistas e sociointeracionistas para seu repensar. Pensar conhecimento em rede, portanto, é ato histórico possível a partir das produções dos sujeitos sociais em interação. Como produção, sofre as contradições e as tentativas de apreensão - e conseqüentes leituras - por parte dos que o tomam como possibilidade de compreensão. Por um lado, há tendências que acabam por lidar com as redes com lógicas semelhantes de aprendizagem aos modelos convencionais de disseminar informações; por outro, as redes exigem dos usuários uma condição de "estar aberto ao novo" para enfrentar os desafios que agregam ao uso e às questões impostas aos modos de buscar informação.
Embora polissêmico, o vocábulo rede configura sua enunciação com uma noção aglutinadora do fazer coletivo. Kohn (1994) assinala que a rede atravessa o espaço, o tempo e a ordem estabelecida, aglutina elementos dispersos, cria um território intersticial onde menos se espera. Como objeto de dupla constituição, espacial e social, nenhuma rede pode existir sem base material e técnico-organizacional, mesmo que reduzida, assim como não pode destituir as relações interpessoais, por serem os sujeitos os tecelões dessa trama. Essa nova metáfora implica, para sua configuração, entradas múltiplas, próprias dos sistemas complexos.

Dialogando com Morin (2001), em busca de sentido para a idéia de complexidade, e alertada de que "todo conhecimento é uma tradução a partir dos estímulos que recebemos do mundo exterior e, ao mesmo tempo, reconstrução mental, primeiramente sob forma perceptiva e depois por palavras, idéias, teorias" (p. 490), passei a assumir determinados conceitos, estabelecidos como guia para o processo de captar o objeto de meu estudo como um sistema complexo, ao mesmo tempo em que ousei discuti-lo por meio de uma formulação que desejou incorporar também modos mais complexos de apreender a realidade - o que o autor chama de instrumentos conceituais.

Ardoino (2001, p. 548-550) chama a atenção de que complexo, ao contrário de simples e claro, que privilegiam um conhecimento baseado na evidência e na transparência, também não se alinha com a acepção ainda subsistente de complicado, mas assume os usos triviais advindos do latim, que lhe conferem os sentidos de tecido, trançado, enroscado, cingido, enlaçado, apreendido pelo pensamento, e que segundo Morin corresponde essencialmente a uma revolução do procedimento de conhecimento que quer manter juntas perspectivas tradicionalmente consideradas antagônicas: universalidade e singularidade.

Para Morin (2001, p. 563), a máxima de Pascal indica a idéia de organização, ou seja, entende que o conceito de sistema leva à idéia de organização, que produz emergências, não expressas nas partes, mas que exigem organização - o todo - para assumir propriedades constitutivas que só se expressam quando orga- 
nizadas em um sistema. Porém, como "a complexidade reconhece a parcela inevitável de desordem e de eventualidade em todas as coisas, ela reconhece a parcela inevitável de incerteza no conhecimento. [...] A complexidade repousa ao mesmo tempo sobre o caráter de 'tecido' e sobre a incerteza” (idem, p. 564).

Meus instrumentos conceituais passaram a ser visibilizados à medida que fui dando-me conta dos limites da minha compreensão. Adotei as sugestões de Ardoino (2001, p. 550-555): complexidade e heterogeneidade (esta constitutiva da complexidade, por sua natureza plural, incluindo o conflito, a alteração, o reconhecimento da importância do tempo e da história para a compreensão dos fenômenos, significando admitir olhar os processos nos funcionamentos específicos, com duração e memória); ambição de domínio (traduzida não pelo sentido de quem tem controle sobre o outro, como capacidade de superioridade e controle, mas pela familiaridade com o objeto, ligada à duração e à experiência; é o domínio de acompanhamento, o que implica mais o tempo do que o espaço, ou seja, domínio, por exemplo, de um artista por sua arte; ou domínio de uma associação de trabalhadores sobre seus processos de luta política); e multirreferencialidade (pluralidade de olhares, tanto concorrentes, quanto eventualmente mantidos unidos por um jogo de articulações, que possibilita, pelos variados sistemas de referência, alterá-los e elaborar significações mestiças, em favor de uma história).

Para captar as redes de conhecimento que tais projetos produziam, como sujeito complexo - o que produziu um giro fundamental e irreversível no meu modo de pensar - , empreendi, então, um processo de investigação visando a alcançar a complexidade presente nas formas como se operavam os programas/ projetos, mas nem sempre visível sem lentes especiais até para pesquisadores experimentados. Este era o desafio: tecer a rede para além dos contatos físicos com os quais operava, sendo capaz de simbolizar as conexões imateriais existentes entre sujeitos e saberes, promovendo atitude de escuta em que pudesse situar os acontecimentos - a experiência - com toda a intensidade que eles geravam. Mas, ao mesmo tem- po, mergulhando fundo nas formulações escritas nos múltiplos documentos coletados, travando um diálogo sistemático, não das faltas, nem das lacunas, mas das consistências inventivas e nômades que continham, e das fragilidades transitórias que os atavam, revelando os liames que se entrelaçavam e rebuscavam as formas de fazer a educação de jovens e adultos sem que, necessariamente, se alterassem as práticas, ou se mudassem os quefazeres pedagógicos, para além dos discursos que enunciavam essas práticas como novas.

Cabia-me fazer emergir a singularidade e a potência de cada programa/projeto, os processos novos e consistentes de participação e de exercício de democracia para sujeitos antes excluídos do direito à educação.

Tentando criar o campo material do corpus teórico que compus, idealizei a ilustração que mostra a teia figurada que se forma entre os projetos selecionados, enredando-os em uma aproximação semelhante à das sinapses na cadeia neuronal - representadas pelas inúmeras pontas das figuras estelares em conexão com outras figuras - que estabelecem relação de contigüidade entre os neurônios, fazendo passar o impulso nervoso, sem que, no entanto, haja desidentificação do que cada um é, da unidade totalizante que forma cada um. O fundo e os espaços entre os projetos constituem o interstício, uma espécie de tecido conjuntivo, o ambiente social de aprendizagens no qual, em última instância, as intervenções pedagógicas se dão no tempo, afetando - ao mesmo tempo em que afetadas por - esse mesmo ambiente. Esse interstício, ocupado pelos fóruns de educação de jovens e adultos, integram em rede os múltiplos projetos/programas, que aí interagem e dialogam. A imagem no plano não demonstra a tridimensionalidade, melhor, a multidimensionalidade, possibilidade espacial de perceber que todo o conjunto se move, não é estático, que estabelece outras relações de maior proximidade, mais diretas ou indiretas, pelo lugar que ocupam em momentos da realidade histórica. A bidimensionalidade representada no plano tem, do mesmo modo que no espaço, os sujeitos de aprendizagem como essência - 
produtores e consumidores de conhecimentos, que se alteram entre si, tanto no interior das instituições quanto nos interstícios.

Figura 1 - Representação da rede de projetos

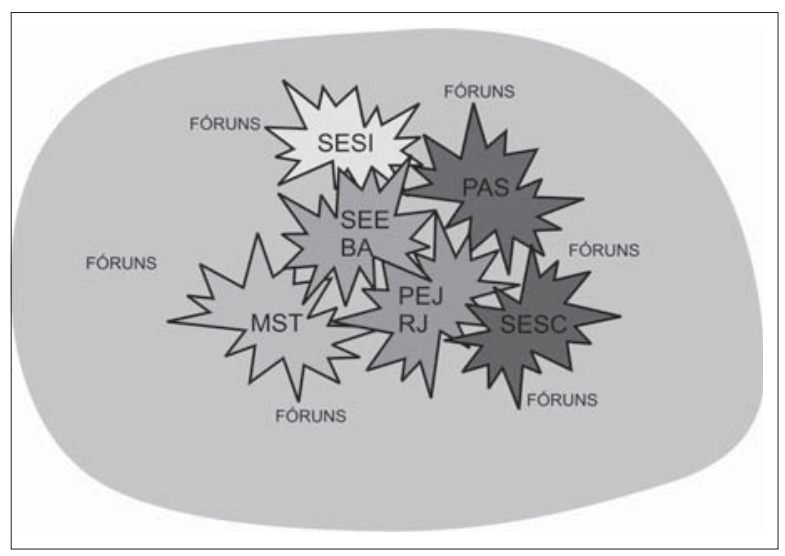

Tal como na célula viva, a relação estabelecida com o meio é de interpenetração, por ser a membrana celular um limite semipermeável, em que moléculas entram e saem da célula, enquanto outras não são capazes de fazê-lo. Mas cada molécula que entra passa a fazer parte da organização celular que sustenta a vida da célula e da rede de relações que estabelece, e faz parte, ainda, das propriedades emergentes da interação. Quando as moléculas atravessam a membrana, transformam a rede de relações, gerando, assim, transformações na identidade - não mais pensada em si e por si mesma, mas no emaranhado relacional coevolutivo (Najmanovich, 2001, p. 24-25).

Os fios que os unem, criando relações entre eles, são atos de aprendizagem, feitos pelas inúmeras situações a que os sujeitos se submetem, em encontros materiais e imateriais - estes do nível do simbólico -, tanto provocadas pela proximidade de afetos e modos de ser/viver/conviver, quanto pelas ferramentas que organizam as próprias situações de aprendizagem: currículos, conteúdos, estrutura didática, organização pedagógica etc.

Neste estudo, tentei compreender que mudanças conceituais ocorreram, por um lado, pelas formas como o Estado, a serviço dos interesses dominantes, regulou os alcances dessas concepções, traduzindo- as como direitos. Por outro, como as compreensões dos sujeitos de direito/não-direito envolvidos com o campo da prática, do fazer cotidiano, ressignificaram e transformaram esses conceitos, apropriando-se deles segundo necessidades, usos, interesses, costumes. Nessa tensão, observei que alguns conceitos, valorizados pela questão ideológica que representavam, permaneceram conservados, passando incólumes na defesa de suas formulações, mas não resistindo a qualquer teste da prática, da experiência, seguindo assim formulados e apregoados, mas encerrando sentidos distintos dos originalmente praticados.

\section{Perspectivas internacionais do direito à educação}

A perspectiva do direito - marco conceitual do porquê educar jovens e adultos - tem fortes enunciações ao longo de toda a história pela qual transitei, embora nem sempre tenha sido assumido da mesma maneira, nem para todos. Da Declaração Universal dos Direitos Humanos, de 1948, passa-se à II Conferência de Educação de Adultos no Canadá, em 1960, em que a perspectiva do direito se explicita pelo reconhecimento do papel dos jovens no esforço da alfabetização. Em 1972, na III Conferência em Tóquio, alguns temas são recorrentes, e já se faz a associação, pela primeira vez, da educação às necessidades humanas, mais tarde traduzidas por necessidades básicas de aprendizagem, recortando a abrangência que nesse momento aparecia. A diferenciação dos segmentos excluídos de direitos faz-se apontando a precária realidade dos jovens seja em relação à escola, seja em relação ao trabalho; a situação de populações rurais desassistidas de escolas; a condição de trabalhadores migrantes, de idosos e desempregados em geral. Em todas elas a condição das mulheres se destaca como objeto de atenção, pela desigualdade que as acomete mais fortemente no interior de cada categoria.

Na alfabetização, é creditada a responsabilidade para o desenvolvimento, e o fundamento da educação de adultos. Meio, e não fim em si mesmo. A educação deve ser funcional, atravessando a sociedade, 
o trabalho, o lazer, as atividades cívicas e, para isso, os governos deveriam tratar a educação de adultos em pé de igualdade à educação escolar, com sensível aumento de investimentos.

A $19^{a}$ Conferência Geral da Organização das Nações Unidas (ONU), em Nairóbi (Quênia), em 1976, aprofunda a idéia do direito de toda pessoa à educação e a uma livre participação na vida cultural, artística e científica, considerando inseparáveis educação e democracia, e educação e abolição de privilégios, a última idéia sob a responsabilidade da educação permanente, por assumir ser a educação de adultos parte integrante da educação permanente. Como tal, a educação permanente é constitutiva do direito à educação, e meio facilitador do exercício do direito à participação na vida política, cultural, artística e científica. Mais uma vez a preocupação com os jovens aparece, recomendando-se sua inclusão na educação permanente até que, integrando o mundo adulto, possam ser beneficiados pela educação de adultos.

$\mathrm{O}$ conceito de educação permanente expressase como forma de um projeto global com vistas a reestruturar o sistema educativo existente, assim como para desenvolver todas as possibilidades de formação fora do sistema educativo, abarcando todas as dimensões da vida e áreas do saber, de modo orgânico, com todos os processos educativos que crianças, jovens e adultos seguem ao longo da vida.

Por educação de adultos entende-se a totalidade dos processos organizados de educação, seja qual for o conteúdo, o nível ou o método, formais ou não-formais, que prolonguem ou recoloquem a educação inicial oferecida nas escolas e universidades, e na forma de aprendizagem profissional, vinculada precipuamente à idéia de desenvolvimento, cara para a década de 1970. A capacidade de aprender a aprender enuncia-se nos termos da Recomendação de Nairóbi.

Paris, em 1985, sedia a IV Conferência, e movimenta-se para definir um termo novo, traduzindo uma ciência equivalente à pedagogia - a andragogia como conhecimento adequado sobre as formas de ensinar e educar adultos, termo que, no entanto, não encontrou eco na prática social. Mantém estreita vin- culação da educação permanente ao desenvolvimento econômico, social, científico e tecnológico do mundo contemporâneo, associando população educada e desenvolvimento econômico. Declara o direito de aprender como desafio capital da humanidade, reconhecendo-o como direito humano fundamental, e destacando que, por esse caráter, não se destina a apenas uma parte da humanidade, com o que critica as formas como os países vêm tratando os desfavorecidos em todas as partes do mundo.

A chegada à V CONFINTEA, em 1997, exige compreender o processo de mudanças instalado na América Latina, conhecido como globalização, referida por Chesnais (1996, p. 14) como mundialização do capital, perda de soberania dos países, em troca da pujança do poder do capital internacional, transnacional e virtual. A contribuição da América Latina marcou lugar, principalmente pelo anúncio da presença juvenil na educação de jovens e adultos, cada vez mais intensa e denunciadora do fracasso dos sistemas públicos e dos acordos em relação à educação básica, ditados pelas agências internacionais de financiamento.

Apesar dessa constatação, no Brasil desse tempo, embora o direito à educação de jovens e adultos não fosse assumido como política pública, de fato é o Estado ainda o potente articulador de políticas. Essas políticas, do ponto de vista da concepção com a qual operavam, nem sempre estavam expressas pelo sentido do direito à educação que eu buscava, mas seguramente pelo financiamento que possibilitavam.

\section{Concepções e sentidos para parceria e financiamento}

O financiamento da educação de jovens e adultos - restrito em períodos recentes, e insuficiente para a demanda atual - é inequívoco pelo modo como enunciou e reconceitualizou o termo parceria, relação indiscutível no fazer da educação de jovens e adultos nos espaços da sociedade. O financiamento, constituindo políticas educacionais, tinha fontes diversas, e o Ministério do Trabalho passou a ser o grande indutor de projetos de educação de jovens e adultos, com o 
Ministério da Educação (MEC) inexpressivamente apoiando algumas quantas ações de formação continuada e de reprodução de material didático. Especialmente durante os oito anos do Governo Fernando Henrique Cardoso, essa situação reforçou-se, pelo esvaziamento do papel do MEC como indutor de atendimento na educação de jovens e adultos - dever constitucional do Estado -, relegando à parceria com a organização não-governamental Alfabetização Solidária (ALFASOL) a responsabilidade do atendimento, de forte concepção compensatória e clientelista, assim como os recursos "carimbados" no orçamento.

A concepção de parceria "resolveu" as questões da educação de jovens e adultos, e esta concepção tomou caráter e visibilidade muito variada, tanto na forma como o poder público a encarnava, quanto pela forma desenvolta como as instituições conformaram seu papel social nesse campo, como parceiras.

Várias foram as concepções de parceria nos projetos em discussão. Uma delas, a que executava uma ação predefinida pelos atores do Estado, submetendo os parceiros a regras e procedimentos não-discutíveis - o caso do Programa Alfabetização Solidária (PAS), que depois levava a mesma prática centralizada para sua ação como organização não-governamental, embora ela própria, a partir de então, passasse a depender de financiamento público para cumprir o modelo antes assegurado, por ser braço executor da política de educação de jovens e adultos da União.

Uma segunda, em que a concepção incluía o parceiro como contribuinte na formulação de propostas, segundo os interesses dos grupos sociais que representava, mas não lhes conferindo qualquer poder de controle sobre os recursos, sobre regras e procedimentos, nem sobre a execução orçamentária, o que cabia a um terceiro parceiro - o caso do Programa Nacional de Educação na Reforma Agrária (PRONERA), com o MST, que dependia/depende da universidade para a execução da ação e em parte para a administração de recursos, centralizados no Instituto Nacional de Reforma Agrária (INCRA).

Uma terceira, em que o Estado, em última instância, era o grande financiador das ações de educa- ção de jovens e adultos pela isenção fiscal, e em que os parceiros atuavam com absoluta autonomia na destinação dos recursos, no que diz respeito às concepções, políticas, prioridades. Concorrendo ainda, muitas vezes, com outras entidades quando novos recursos públicos ou internacionais eram oferecidos, com larga vantagem sobre outras instituições, devido ao porte, à inserção do segmento que representavam, às gestões de nível macro da qual participavam. É o caso do Serviço Social da Indústria (SESI) e do Serviço Social do Comércio (SESC), embora este último viesse demonstrando maior independência de novos recursos, como parceiro do Programa Brasil Alfabetizado, por exemplo, em movimento inverso: aportou recursos de seu próprio orçamento, provenientes da contribuição obrigatória calculada sobre a folha de pagamentos, recolhida pelo Instituto Nacional do Seguro Social (INSS) e devolvida aos integrantes do chamado Sistema S para a execução da formação continuada de alfabetizadores, equipe técnica e supervisores, sem recorrer a novo financiamento do governo federal.

Uma quarta, em que a educação de jovens e adultos foi realizada com aportes de recursos não apenas das próprias administrações que as desenvolveram, mas também com recursos da parceria do governo federal, em projetos voltados ao apoio a ações de formação continuada de professores e outras menores, complementares, ou alquimizadas em subterfúgios de outros programas com financiamento, utilizados desde a exclusão da educação de jovens e adultos no Fundo Nacional de Manutenção e Desenvolvimento do Ensino Fundamental e de Valorização do Magistério (FUNDEF) - o caso da Secretaria de Educação da Bahia, nessa última situação, e do município do Rio de Janeiro, que tem atendimento restrito na rede, mas vem sendo usuário sistemático de recursos do Fundo Nacional de Desenvolvimento da Educação (FNDE) para formação continuada de professores.

Embora não tenha sido objeto da discussão na pesquisa, uma quinta forma vem-se delineando desde 2003, quando o MEC lançou o Programa Brasil Alfabetizado, por meio do qual as diversas concep- 
ções circulantes de alfabetização podem ser apoiadas com financiamento para um período de tempo entre seis e oito meses, na proposta validada desde 2004. Esse período de tempo nem restringe, nem exclui, no entanto, qualquer desenho de ação do parceiro, quer do ponto de vista das concepções de alfabetização, quer dos tempos de execução. O parceiro executor da ação tem liberdade para integrar novos recursos ao projeto pedagógico, ampliando quantitativamente o atendimento e mantendo seu "modelo" de ação pedagógica, segundo concepções de alfabetização, de tempos de aprendizagem, de organização dos cursos, de duração, sem ferir as regras do financiamento federal.

Esses modos de fazer a parceria podem acontecer integrados, e cada instituição, dependendo do momento, pode também realizar concomitantemente mais de uma forma, desde que as regras admitam a concorrência a recursos, pela natureza da entidade que o pleiteia. Duas constatações, entretanto, devem ser feitas. Uma reconhece que, nas parcerias, a busca dos recursos públicos tem sido arquiteturas bem-montadas de financiar o setor privado, escoando recursos do erário para esse fim, e impedindo, por outros mecanismos, que não cabe discutir nesse âmbito, o acesso de diversas instâncias do sistema público seja federal, estadual, municipal, autárquico, fundacional etc. a esses novos recursos. O PAS, principalmente, emblematiza, de meados da década de 1990 para cá, algumas formas de como se faz a conexão nas relações público/privado, revelando a promiscuidade do Estado com a esfera privada, no âmbito do neoliberalismo. A outra, sem negar a parceria como estratégia política de alcançar o direito, reafirma o dever constitucional do Estado com esse direito, não o eximindo da responsabilidade que lhe cabe.

\section{Compreensões da pesquisa}

Embora o atual momento ofereça um rico campo de compreensões com marcas muito peculiares, reveladoras das produções de uma sociedade em movimento de democratização, ganhando experiência e experimentando práticas diversas das reconhecida- mente autoritárias que forjaram outros momentos da história do país e da educação, muitas pistas ainda poderão ser mais bem compreendidas na interlocução que, necessariamente, o trabalho de pesquisa realizado produzirá.

As nove grandes compreensões por mim produzidas, em relação aos seis projetos tratados e à rede de conhecimentos em que se inserem/inseriram, estão sintetizadas a seguir, em prosseguimento à discussão inicial quanto ao pano de fundo do direito à educação, do ponto de vista internacional, e ao aspecto das parcerias e financiamentos por meio dos quais são executados.

Primeira compreensão:

Os fóruns - tecidos conjuntivos constituindo redes de projetos

Algumas compreensões bastante relevantes se destacaram dos projetos e, em busca dos sentidos que vão sendo atribuídos à educação de jovens e adultos, nesse cenário da contemporaneidade, passo a discutilas. Uma primeira diz respeito à forma como os projetos, representados pela ilustração da rede que se interconecta, mostraram-se permeáveis à interferência e à produção da rede sob a qual busquei compreendê-los.

Essa afirmação visibilizou-se, no âmbito da pesquisa, por meio de algumas evidências e institucionalidades que se constituíram e que não mais os mantiveram isolados, mas integrados no mesmo tecido com o qual estabeleciam trocas, interpenetrações, parcerias, vínculos. Como evidências, aponto duas importantes: a disseminação dos sentidos da educação de jovens e adultos como direito; a apropriação do papel do Estado como parceiro potente e fomentador de ações e de novas concepções no campo.

Desde quando a ação na educação de jovens e adultos era intensa, mas desconectada no espaço-tempo, sem um tecido conjuntivo agregador, os fóruns resgataram o reconhecimento entre os tantos atores, agora em relação, em rede, cujas conectividades exigem maior compreensão e investigação. Não sendo os 
fóruns meu foco principal, tomei a materialidade da existência com a qual vêm refazendo a educação de jovens e adultos, pela conquista da legitimidade do papel que representam. Atuando como interstício das múltiplas trocas, injunções e disjunções que as instituições/programas/projetos realizam, os fóruns, de modo permeável e contiguamente, por meio de pessoas - variados atores imbricados desde os níveis centrais à base da ação na qual a prática pedagógica acontece em movimento de ir-e-vir -, novamente permeabilizam as redes de contato e experiências entre atores e instituições.

A identidade desses fóruns produz-se, em maior ou menor escala, pela busca constante da garantia do direito à educação de jovens e adultos, em espaços de interlocução entre entidades públicas e privadas, governamentais e não-governamentais, formais e nãoformais, representadas por administrações públicas estaduais e municipais, tanto da educação quanto de áreas afins, nas suas diversas instâncias de realização: universidades e institutos superiores de educação; Sistema S, representado pelo SESC, SESI, Serviço Nacional de Aprendizagem Rural (SENAR); ${ }^{4}$ organizações não-governamentais; sindicatos e federações; entidades filantrópicas e comunitárias; movimentos sociais; estudantes universitários e de educação de jovens e adultos; professores, alfabetizadores, educadores populares. As identidades vão sendo estabelecidas nas negociações de sentidos para os temas/problemas atinentes à área, que passam a configurar o perfil de cada fórum, assim como interferem nas concepções e práticas de atores, projetos e instituições ali representadas. A isso chamo permeabilidade, em interação dinâmica que constrói e reconstrói sentidos, ressemantizando o campo da educação de jovens e adultos.

Para a constituição do direito, a proposta dos fóruns estende-se da interlocução com agentes e diri-

4 Destaco que, embora esses sejam os integrantes do Sistema S mais presentes nos fóruns, o sistema é constituído de várias outras entidades, as quais não foram abordadas na pesquisa. gentes estatais, formuladores e executores de políticas, programas e projetos à intervenção direta nas políticas públicas, educação de jovens e adultos de âmbito local, regional ou nacional. O exercício da democracia segue como desafio para a convivência e o diálogo entre atores tão diversos, com missões e objetivos às vezes até mesmo conflitantes, que demandam a escuta, a possibilidade de divergir, de tensionar idéias, negociar e construir saídas e alternativas pactuadas por todos.

Entendi, desde que enunciei o "modelo" de relações estabelecidas, que o tecido em que se dão as trocas na contemporaneidade, representado pelos fóruns de educação de jovens e adultos, tem constituído novas institucionalidades que se forjam no tempo-espaço nacional, ao longo de dez anos.

A legitimidade desses espaços de produção - os fóruns, aos quais se atribui a categoria de movimento social - vem sendo reconhecida, no atual momento histórico, pelo governo federal que, identificando a potência das articulações políticas e ideológicas ali realizadas, tem mantido com eles canais de interlocução direta e formal visando à elaboração, consolidação, avanço e enraizamento das políticas públicas de direito à educação de jovens e adultos.

\section{Duas compreensões revelam o sentido do direito à educação}

Uma segunda compreensão - a educação como direito humano, continuadamente reafirmada, que ganhou força nas últimas décadas, mais para o sentido das enunciações do que para as formas como as políticas públicas resguardaram esse direito - é um princípio indiscutível na educação de jovens e adultos. Se o poder econômico tem sido o grande fazedor de políticas educacionais, nos tempos de globalização, afetando diuturnamente as organizações e prioridades dos sistemas públicos e regulando todos os elementos integradores, a partir do custo-aluno/ano, no trato da educação de jovens e adultos a questão tem sido ainda mais complexa, no marco do direito. Dados quantitativos de população e de escolaridade 
não deixam dúvidas sobre o não-cumprimento do direito, e nenhuma garantia jurídico-legal tem sido suficiente para alterar a sistemática ruptura com o dever da oferta, por parte dos poderes públicos, organicamente, nos sistemas de ensino. Mas a proclamação dos direitos é feita em textos legais, programas, projetos, pareceres, documentos. Não é, portanto, por falta da letra, nem da lei, nem de outros usos da cultura escrita, que o direito não se faz prática, mas principalmente porque o contexto em que se promove e se defende esse direito é fortemente desigual, produtor de exclusões, porque o mundo em que é reivindicado se rege pela ideologia do capital, para o qual a desigualdade é fundamento, e não a eqüidade.

Em contrapartida, não há como negar o potente papel indutor do Estado no fazer das políticas, mesmo quando tímidas, nem há como dispensar o Estado da responsabilidade com a educação de jovens e adultos. O jogo de forças entre níveis e modalidades todos com recursos escassos -, entre público e privado, entre a modalidade presencial e a distância, na educação de jovens e adultos, põe-se desfavoravelmente contra esta. O imaginário social que invisibiliza os não-alfabetizados/não-escolarizados, com o concurso dos meios de comunicação, ou que elege as crianças e os adolescentes como prioridade, absolve o Estado pelo não-cumprimento de um dever, por considerar cada sujeito interditado do direito como culpado pela própria condição.

A conta dos largos contingentes, em um país como o Brasil, só pode ser saldada por meio da presença forte do Estado, envolvendo diferentes atores em rede, com projetos de longo prazo e sustentados como de interesse nacional, com todos os efetivos e potenciais atores sociais que se põem em movimento pela educação de jovens e adultos. No caso da educação de jovens e adultos, por exemplo, a desresponsabilização do setor público como promotor de políticas não impede que o programa permaneça no tempo (desde 1985), apesar das várias ameaças de rompimento, mas não assumindo a educação de jovens e adultos como dever municipal, porque as ofertas nunca foram intensificadas quantitativamente, e nunca le- varam em conta a população demandante, mesmo com a existência de uma rede de escolas públicas com 1.054 unidades.

Todavia, a constituição do direito, com todas as imbricações que consegui capturar, exige-me formular mais uma pergunta: Em que medida o direito, compreendido nos limites dos projetos estudados, revelam de fato a conquista social do sentido que direito pode assumir nas sociedades contemporâneas, ou: seria este direito feito sob a tutela do Estado, e, portanto, frágil conquista que pode ruir quando esse poder sair de cena?

Uma terceira compreensão diz respeito à forma como a educação de jovens e adultos se espraiou pela sociedade brasileira, tanto se alargando em projetos que têm dimensão nacional, ocupando muitos estados e localidades, como também atingindo contingentes expressivos de público.

A história da educação de jovens e adultos no Brasil, não se pode esquecer, foi constituída como uma história de experiências, porque, de modo geral, não conseguiu produzir enraizamentos nos sistemas públicos. Algumas fogem dessa categoria, como o Movimento de Educação de Base (MEB), por exemplo, efetivamente nacional em poucos meses de ação, e o Movimento Brasileiro de Alfabetização (MOBRAL), que como programa de governo constituiu política pública em rede de atendimento, mas paralela ao sistema. O caso mais recente do PAS, de larga penetração, não ultrapassa o lugar de experiência, no meu entender, porque embora oferta oficial, mobilizando formalmente a rede de instituições de ensino superior, mantém um modelo de atendimento "volátil", com duração curta e alta rotatividade dos alfabetizadores, cujo vínculo interessa mais à geração de emprego e renda do que à tarefa alfabetizadora, o que não enraíza sequer o esforço da formação. São, no entanto, as experiências expressas em pequenos projetos de educação popular, de poucos participantes e localizadas, as que demarcam com intensidade a história da educação de jovens e adultos, no tempo e no espaço nacional.

Os programas em discussão na pesquisa, no entanto, não podem ser considerados experiências, no 
sentido clássico da educação popular, em busca da produção de alternativa às concepções hegemônicas.

O SESI, na atualidade, atende cerca de 1 milhão de alunos na própria rede, e teve meta, pelo terceiro ano consecutivo, de 300 mil alunos em alfabetização, e previsão de 1,1 milhão de alunos para 2006; somado ao atendimento do PAS, em alfabetização, com 629.843 alunos em 2004; à Secretaria de Educação do Estado da Bahia, com rede regional de atendimento com 250 mil alunos, dos quais 86 mil de ensino médio, em 417 municípios; à Secretaria Municipal de Educação do Rio de Janeiro, com 32 mil alunos em 118 escolas; ao MST com 30 mil alfabetizandos; e ao SESC Ler, com atendimento da ordem de quase 6 mil alunos, em cerca de 70 unidades, compõem um quadro bastante expressivo, ainda que predominantemente realizado na esfera na alfabetização, demandando expansão e constituição do direito para a continuidade da escolarização.

Para todas essas iniciativas, os recursos públicos a potência do Estado como indutor de políticas - foram/são expressivos, respondendo pela grande parte das metas atingidas, pelo menos, no campo da alfabetização e da formação continuada de professores das administrações públicas, assim como significaram a perspectiva de continuidade, na maioria dos casos em que o atendimento se restringia à alfabetização, ou ao primeiro segmento do ensino fundamental. A articulação entre esses programas/projetos ainda não pode ser considerada uma realidade como política, mas faz-se pela busca de cada aluno que deseja dar continuidade aos estudos. Essa demanda "não-intencionalmente organizada" pressiona os sistemas para a oferta do atendimento, e gradativamente impõe a eles a compreensão de que o fazem como dever público a sujeitos de direito, o que altera os planos, as prioridades, as políticas locais. Entre os programas, por exemplo, o MST parte de uma outra lógica, porque seu compromisso com a educação se integra a um novo projeto de sociedade, pelo qual os trabalhadores sem-terra organizados vêm lutando. Não é a demanda, portanto, que pressiona o atendimento, mas a certeza de que qualquer projeto de transformação social exige foco na edu- cação, sem limites na sua compreensão: da alfabetização à universidade; do cumprimento do direito ao ensino fundamental, da conquista à escola média à formação continuada; da educação técnica à profissional; do aprender por toda a vida.

\section{Duas novas compreensões pela "presença freireana"}

A presença de Paulo Freire é forte referência na educação de jovens e adultos, o que implica dizer que há influências do seu pensamento no modo de propor a educação para o público jovem e adulto, embora muitas vezes as formulações e as práticas ainda não revelem os efeitos dessa referência.

Uma quarta compreensão, portanto, expressa-se na existência de uma concordância ou convergência nos projetos/propostas quanto ao significado de Paulo Freire para a educação de jovens e adultos, muitos inclusive apontando seus aportes teóricos como fundamentos, embora, na prática, se perceba pouca relação entre as concepções que sustentam o pensamento do educador e as que revelam os projetos, ou que os organizam. A cultura, como esteio da educação, por exemplo, mesmo na concepção do MST, é pouco visibilizada, o que não significa necessariamente ausência, diante das características que se observam em muitas práticas, presentes no fazer cotidiano dos projetos, mas não enunciadas nos currículos. Nas formulações dos projetos na Bahia, as marcas das concepções freireanas são evidentes, especialmente na definição de currículos pensados em função das características dos sujeitos, expressos em diversos programas em resposta às necessidades dos demandantes, tanto nas ofertas culturais que a prática vem sugerindo, como nas formas de atendimento, organizadas não apenas em unidades escolares, mas especificamente em centros de educação de jovens e adultos e, para o caso de exames, em comissões de avaliação (vinculadas às unidades escolares), com ofertas mensais permanentes.

Nessa compreensão, observaram-se aspectos relacionados à duração dos programas/projetos, aos tempos escolares, às formas de organizá-los, às pro- 
postas curriculares, à avaliação etc., com poucas enunciações diferenciadas da escola regular. A organização do projeto, por exemplo, em blocos, etapas e unidades de progressão surge no Programa de Educação de Jovens e Adultos (PEJA), embora sua identificação com a educação de jovens e adultos sempre esteja associada, nas falas docentes, à estrutura seriada para destacar a que correspondem. Embora com componentes curriculares bem demarcados, nas práticas relatadas principalmente pelos docentes do segundo segmento do ensino fundamental, ainda se observou ser este um ponto de muita dificuldade: professores de disciplinas específicas custavam a conceber novas práticas curriculares em função de um outro projeto pedagógico, nem sempre exercitando as possibilidades que a concepção do PEJA admite.

No caso da educação de jovens e adultos na Bahia, a forma de organização do Programa de ensino fundamental para jovens e adultos apresentava ruptura com modelos tradicionais, para apresentar unidades conceituais, organizadoras do processo de aprendizagem, cujo conjunto de conhecimentos pode atender a diversas interpretações e, conseqüentemente, a campos conceituais diferenciados, em razão do avanço da ciência, da técnica, da tecnologia, não ficando presos a conteúdos muitas vezes ultrapassados. Não segue nem série, nem fase, nem ciclo; tem a unidade conceitual como organizadora do momento de aprendizagem.

A presença freireana levou a outras apreensões dela decorrentes. Portanto, uma quinta compreensão apresentava-se: a exigência de processos continuados de formação e de apreensão dos possíveis sentidos da educação de jovens e adultos, como forma de ampliar as concepções correntes entre professores, especialmente nas práticas pedagógicas.

De modo significativo, a escolarização de jovens e adultos, apesar dos avanços na conformação da área, ainda reproduz e se define como uma escola de parâmetros fortemente restritos ao modelo convencional, regular, ela mesma anacrônica para crianças e, con- seqüentemente, alheia ao tempo-espaço histórico e social da vida de jovens e adultos. Sofre ruptura também quando se verifica, nas enunciações de vários projetos, a dimensão do aprender por toda a vida; sempre é tempo de aprender-MST; SESC Ler; SESI Educação do Trabalhador.

Mesmo essas propostas não têm construções concretas que possibilitem a realização dessa dimensão, a não ser no caso do MST, em que se imbricam formação de educadores e escolarização e, ainda, a formação inclui o tempo escola e o tempo comunidade, demonstrando que as aprendizagens se fazem para além dos muros da escola - ou das "quatro paredes da sala de aula", situação mais provável, embora essa formação gire, também, em torno da escolarização. A formação política dos educadores militantes, como se referiram vários educadores, ultrapassa a dimensão escolar, mas mesmo esta não fica exatamente visível na enunciação do que o MST compreende como educação de jovens e adultos. Nesse caso, a dimensão do aprender por toda a vida acontece para militantes, lideranças, educadores, mas habita o terreno da informalidade, não estando incluído na intencionalidade da educação de jovens e adultos. A pedagogia da educação de jovens e adultos no MST, segundo a concepção registrada, está sendo produzida e maturada, embora faça parte, desde então, da pedagogia do movimento, que, esta sim, tem clara dimensão educativa em todas as ações da luta. A chegada a esse outro patamar de compreensão inegavelmente acontecerá, pelos modos e processos pelos quais o movimento vem, dinamicamente, dialogando com a realidade e com os estudos.

Cabe apostar, entretanto, na continuidade do entranhamento das idéias de Freire nas reflexões dos educadores, possibilitando maior aproximação e compreensão das práticas pedagógicas.

Alguns outros autores - por exemplo Emilia Ferreiro e Magda Soares - também são recorrentes, principalmente no que tange à alfabetização, embora nem sempre sejam visíveis suas teorizações nos modos de alfabetizar jovens e adultos. 


\author{
Sexta compreensão: \\ Sucesso e continuidade na \\ educação de jovens e adultos
}

Uma sexta compreensão imbrica-se diretamente com a avaliação, em sentido amplo, nos modos como ela organiza a oferta pedagógica e por ela possibilita o percurso de sujeitos em programas/projetos, concorrendo para a construção do sentido do direito.

Observou-se, por exemplo, convergência de enunciações quanto à entrada e saída de alunos a qualquer tempo, segundo seu desempenho e desenvolvimento, o que a prática, no entanto, nem sempre tendeu a confirmar. Nas redes escolares, principalmente, as lógicas da organização racional dos docentes, distribuição de cargas horárias pelas unidades escolares, fatores como licenças, afastamentos, aposentadorias interferem sobremaneira para que os projetos possam atender a essa premissa da educação de jovens e adultos. Além disso, as organizações formais são pouco propensas a mudanças que ameacem os controles instituídos e os modelos em curso, exigindo modificações nos procedimentos de acompanhamento e controle, o que do ponto de vista organizacional costuma ser mal recebido.

Os tempos de aprendizagem e os tempos de duração dos projetos conflitam permanentemente. Horários inadequados de entrada e saída obedecem a interesses das instituições, negociando pouco os interesses dos alunos. Chocam-se com horários de trabalho, tempos de deslocamentos até a escola, quando não punem os atrasos com novas interdições. A duração do projeto muitas vezes se coloca como tempo de permanência do aluno, e não como referência de organização pedagógica. A premissa de que a matrícula se pode dar a qualquer tempo, e de que a saída pode decorrer do sucesso alcançado, segundo ritmos de aprendizagem variados tão logo tenha o domínio (no sentido de Ardoino, 2001) do conhecimento, não tem sido exercitada, de fato, nos projetos instituídos. A cultura de uma nova relação entre os sujeitos e o processo de aprendizagem, indispensável à educação de jovens e adultos, demanda abrir mão da cultura do controle, que funde burocracia e autoritarismo. A saída, derivada de outros fatores que não o sucesso, não deve ser interpretada sempre como evasão, se o aluno não volta à escola. A educação de jovens e adultos aponta para interrupções freqüentes, diante de fortes motivos da vida adulta (impostos também aos jovens): um emprego, mudança de local de trabalho, mudança de local de moradia, doenças (pessoais e com familiares), estrutura familiar que se altera, exigindo maior participação de quem estudava etc.

\section{Sétima compreensão: \\ Concepções de formação \\ continuada de professores}

Uma sétima compreensão diz respeito à pregnância de concepções de formação continuada às práticas pedagógicas e às “artes de fazer” (Certeau, 1994) o currículo. Tendo como princípio o entendimento de que os saberes, produzidos ao longo da vida pelos sujeitos praticantes, são a base sobre a qual assentam seu estar no mundo, sua compreensão e as explicações sobre ele, a educação de jovens e adultos faz-se viva para sujeitos professores, eles também jovens e adultos em processos de metacognição sobre o aprender de seus alunos, produzindo conhecimentos, nem sempre suficientes para possibilitar a continuidade dos processos de aprendizagem e adequados para criar ambientes satisfatórios ao aprendizado do que deve compor o currículo na educação de jovens e adultos.

Os modos de fazer a formação, junto a professores que já vivenciaram, em outros projetos, também outras concepções; de valorizar as ações e fazer emergir as práticas cotidianas de sala de aula e confrontálas; assim como confrontar as concepções docentes, constituem fundamentos da metodologia de trabalho expressa em alguns programas/projetos, que têm no princípio de aprender por toda a vida o entendimento de que professores são também jovens e adultos formando-se e constituindo-se como pessoas e profissionais nesses processos de interação e diálogo estabelecidos com seus pares, mediados pelos formadores em relação aos conhecimentos. A circulação de 
alfabetizadores e professores por diversos projetos contribui para a constituição da rede, conectando suas percepções, saberes, práticas pedagógicas e subjetividades, e impregnando as práticas - mais que as concepções - de outros projetos.

O desafio de construir processos de formação continuada para professores tem significado a possibilidade de concretizar idéias forjadas durante anos de trajetória na educação de jovens e adultos e de estimular a luta por espaços legais, institucionais, em que os projetos políticos de atendimento pela escola e da educação de jovens e adultos se façam como direito, fortalecendo os professores para intervir na realidade social, educacional e pedagógica, de forma qualificada, consciente e significativa.

Essa concepção de formação, evidentemente, tem relação direta com o perfil dos professores - sob todas as possíveis denominações -, nem sempre um profissional qualificado para a atividade que exerce. Em um extremo, cito o caso do PAS, em que o voluntariado é predominante, além da rotatividade do alfabetizador a cada projeto, como alternativa inaugural de oferta de trabalho precarizado, diante da concepção compensatória do programa. No outro extremo, o SESI, em que a profissionalização da educação de jovens e adultos é visível, não apenas pelo contrato formal nos projetos institucionais, com remunerações normalmente acima da média, como pela existência de outras funções pedagógicas na rede de atendimento, que promovem o acompanhamento, a formação continuada. A assunção da formação de qualidade levou a entidade à formulação, em parceria com a Universidade de Brasília, de um curso de especialização a distância em educação de jovens e adultos, privilegiando o público interno, mas também com vagas para candidatos externos, cuja duração demonstra o compromisso com a profissionalização das equipes que atuam na área. No caso do MST, em que muitas vezes o educador não tem nem escolaridade, nem formação para a função docente, o caráter da militância aparece como forte atributo que o desafia a realizar a formação, superando as barreiras existentes, pela premissa de que todos são educadores do povo e de que todos são capazes de aprender. A profusão de documentos de formação, de eventos formativos e de registros das práticas evidencia um modus operandi tão relevante quanto o do SESI, embora partindo de um sujeito inicialmente com formação diversa. A existência dos cursos de pedagogia da terra, em muitos estados, em parceria com universidades, é emblemática quanto ao poder desafiador que o MST produz pela educação. No estado da Bahia, a formação continuada não consegue atingir toda a rede, o que vem sendo tentado, nos últimos tempos, pelas teleconferências, na tentativa de fazer-se chegar a um público docente maior. Sobretudo, as formações não são espaços apenas de aperfeiçoamento profissional o caso do PEJA, com sucessivos projetos de extensão universitária para a formação continuada de professores -, mas de deliberação e formulação de programas, projetos, políticas, em situações coletivas - o caso da Bahia, do MST -, demonstrando, também, o crescente envolvimento das universidades com a educação de jovens e adultos, principalmente pela assunção de um preciso papel junto à formação inicial e continuada.

O que se destacou, nas concepções de formação, foi a compreensão de que, para a educação de jovens e adultos, não cabia restringi-la à técnica, mas principalmente resgatar o compromisso político exaltado por Freire, pela exigência da militância docente na construção política do direito à educação, para além da prática pedagógica.

\section{Oitava compreensão:}

Sujeitos alunos - foco e identidades

Outra compreensão, a oitava, diz respeito a como os programas/projetos são formulados, muitas vezes não centrando o foco nos sujeitos concretos para os quais se pensa a proposta educativa. Surgem alunos cujo perfil revela a presença de jovens que, não concluindo a escola regular, são "empurrados" para o noturno, pelas armadilhas sutis que o poder sabe bem dispor. Alunos que "fracassam" de muitas formas considerado o fracasso desde a indisciplina aos resul- 
tados processuais e finais causados pela desmotivação com as propostas pedagógicas - são "convidados" à matrícula no noturno, pelos gestores das escolas regulares, chegando crescentemente em número à educação de jovens e adultos.

Mas os programas/projetos nem sempre são precisos no pensar o sujeito da educação, suas peculiaridades e singularidades, antes de formular as propostas. Observe-se, por exemplo: no caso do SESC, não há distinção da condição de sujeito trabalhador, mas a entidade olha o entorno, a comunidade como público de atendimento; no SESI, a produção é sempre orientada pelo sujeito trabalhador da indústria, o trabalhador assume o lugar do foco enunciativo, mesmo quando se atende toda a comunidade; no PEJA, há prevalência histórica da concepção do direito para alguns - jovens (embora de há algum tempo o direito de acesso dos adultos esteja assegurado). No MST, especificamente, há vínculo estreito com o trabalhador do campo, uma preocupação com a identidade sem-terra, tanto marcada pela redignificação, quanto pelas singularidades que expressa, seu lugar no mundo, sua condição de cidadão.

Observação significativa diz respeito a como esses sujeitos contribuem também na construção dessa rede de projetos - tal como os alfabetizadores e professores -, porque, em muitos casos, não obtendo sucesso em programas de duração curta, circulam por vários outros, em busca do aprendizado, conhecendo e diferenciando as "vantagens" que cada um deles oferece.

Uma das identidades mais presentes em projetos de alfabetização está posta pelo lugar de analfabeto, criando um modo próprio de pensar a ação educativa a partir dessa condição de marginalizado das práticas de leitura e de escrita. Embora essa condição ajude a configurar o campo semântico dos sujeitos, não revela a imensa diversidade que permanece encoberta, e que pelo fato de se manter razoavelmente homogênea, do ponto de vista das categorias socialmente desfavorecidas, não se mostra suficiente para subsidiar propostas de atendimento que exigem reconhecer a cultura como locus da prática pedagógica. No momento atual, o poder público avança na constru- ção da identidade desses sujeitos, quando desde 2003 criou o cadastro de alfabetizandos (e de alfabetizadores), passando a visibilizá-los a partir de sua identidade civil, cor, sexo, local de moradia, história de escolarização. Deixaram, assim, de ser números contabilizados, para serem reconhecidos como pessoas talvez um grande passo para atribuir-lhes, de fato, o direito público subjetivo.

Nona compreensão:

Concepções de alfabetização

A nona compreensão, quanto às concepções de alfabetização e sua continuidade, que refletem a dimensão escolarizada da educação de jovens e adultos, são as formas mais evidentes de atribuir sentido à educação de jovens e adultos, ainda que os marcos internacionais apontem para a dimensão do aprender por toda a vida como o verdadeiro sentido da área, reafirmado pelo parecer CNE n. 11/2000. As diversas concepções pelas quais a alfabetização vai passando, assim como a educação de jovens e adultos, são, de modo geral, sincrônicas, e não seqüentes, o que exige pensá-las num espaço-tempo não-linear, mas multidimensional.

Parece haver clareza conceitual de que só a mera alfabetização não basta para conferir status de leitor e escritor da realidade aos sujeitos jovens e adultos, mas que esta é indispensável como integrante da educação de jovens e adultos, da qual não deve estar desconectada, como etapa isolada, não integrada, pela certeza das inconsistências na trajetória de tantos sujeitos, que passaram por campanhas, programas e projetos de curto prazo. Pensar um projeto para jovens e adultos nesta dimensão exige planejar um caminho mais amplo que chegue, pelo menos, ao ensino fundamental completo - o nível reconhecido como de direito universal pela Constituição de 1988. Essa observação, constatada na Avaliação diagnóstica dos programas Brasil Alfabetizado e Fazendo Escola (2005), traz a indispensável determinação de que o ato de alfabetizar não pode ser reduzido a um tênue curso de alguns meses, pelas múltiplas apreensões que 
exige dos sujeitos, que se fazem no tempo, e não apenas no espaço entre um ou outro mandato político.

Apesar de haver concordância com essa concepção, em praticamente todos os projetos, a realidade dos financiamentos apequena-os, e resumem-se ao tempo dos recursos, tirando do centro os sujeitos e suas necessidades básicas de aprendizagem, mesmo quando as concepções originais prevêem tempos mais largos. A inexistência de projetos de leitura, de bibliotecas, de vivências culturais ajuda a reforçar essa dimensão escolar estreita, que ainda perdura na maior parte das propostas. O PAS, por um tempo, fez uma doação de acervos de literatura infantil, mas na atualidade não há registro de continuidade dessa ação. $\mathrm{O}$ SESC Ler, de ocorrência nos espaços arquitetônicos nos quais muitas vezes se situa, dispõe de sala de leitura e biblioteca, mas não se apreendeu qualquer informação sobre de que modo operam, imbricadas com a alfabetização.

O momento atual avança no sentido de melhor reconhecer o que configura o campo das iniciativas de alfabetização no país, quando o MEC propõe e desenvolve um mapeamento das iniciativas de alfabetização.

\section{Finalizando}

\section{Visões atuais da trama e do direito \\ à educação de jovens e adultos}

Finalizando, posso dizer que a pesquisa me levou mais a desenhar as tendências que a educação de jovens e adultos assumiu, como um campo político em disputa pelo direito, tensionando a esfera pública estatal a garantir e manter modos de oferta, do que pela disputa de incorporações nos instrumentos legais que podem consolidar a educação de jovens e adultos nos orçamentos, assegurando organicamente políticas de atendimento: planos estaduais e municipais de educação, em sua maioria, estão por serem construídos, configurando um espaço novo de possibilidades para a inclusão da educação de jovens e adultos no campo dos direitos. A efemeridade dos programas/projetos, mesmo quando concertados pelo governo federal, como no momento atual, com intenções e concepções evidenciando o compromisso com o direito, esbarram nas disputas internas e não contam com o povo na rua, nem com a pressão de jovens e adultos exigindo esse direito.

Mas há um novo desenho fazendo-se na paisagem do país, produzido quase silenciosamente pelo trabalho dos fóruns, com efetiva interferência nas concepções e práticas de educação de jovens e adultos, porque realizado como formação continuada, exercitando o método democrático e pautado na cidadania. Esse desenho, tramado nos espaços cotidianos, com táticas de ocasião, tem alterado as agendas e enredado nos fios novos interlocutores para a mesma causa. O cenário - a teia - é favorável e as disposições, recíprocas, possibilitam manter desenhos tramados na espera, nas escolhas, nas lutas, e na certeza de que as lições de hoje devem ser relembradas sempre, porque a educação de adultos, como um direito não-dado, mas arrancado do chão, não pode mais escapar das mãos dos que por ele têm despendido a vida.

\section{Referências bibliográficas}

ALVES, Nilda. Tecer conhecimento em rede. In: ALVES, Nilda; GARCIA, Regina Leite (Orgs.). O sentido da escola. Rio de Janeiro: DP\&A, 2002. p. 111-120.

Trajetórias e redes na formação de professores. Rio de Janeiro: DP\&A, 1998.

ARDOINO, Jacques. A complexidade. In: MORIN, Edgar. A religação dos saberes. O desafio do século XXI. Rio de Janeiro: Bertrand Brasil, 2001. p. 548-558.

BOBBIO, Norberto. A era dos direitos. Tradução Carlos Nelson Coutinho. Rio de Janeiro: Campus, 1992.

BRANDÃO, Carlos Rodrigues. Pensar a prática. Escritos de viagem e estudos sobre a educação. São Paulo: Loyola, 1984. (Coleção Educação Popular n. 1).

BRASIL. Conselho Nacional de Educação. Parecer CNE n. 11/ 2000. Diretrizes Curriculares para a Educação de Jovens e Adultos. Brasília: MEC, maio 2000.

MEC/UNESCO. Projeto de avaliação diagnóstica da educação de jovens e adultos: Programas Brasil Alfabetizado e Fazendo Escola. Brasília: MEC/SECAD-UNESCO, mar. 2005. 
Tramando concepções e sentidos para redizer o direito à educação de jovens e adultos

CERTEAU, Michel de. A invenção do cotidiano: artes de fazer. Petrópolis, Rio de Janeiro: Vozes, 1994.

CHESNAIS, François. A mundialização do capital. Tradução Silvana Finzi Foá. São Paulo: Xamã, 1996.

ECO, Umberto. Obra aberta. São Paulo: Perspectiva, 1988.

GUIMARÃES ROSA, João. Grande sertão: veredas. Rio de Janeiro: Nova Fronteira, 1986.

KOHN, Ruth Cesar. A noção de rede. Tradução Nilda Alves. In:

CHARLOT, B. (coord.). L'école et le territoire: espaces, nouveaux enjeux. Paris: Armand Collin, 1994.

MORIN, Edgar. A religação dos saberes. O desafio do século XXI. Rio de Janeiro: Bertrand Brasil, 2001.

NAJMANOVICH, Denise. O sujeito encarnado; questões para pesquisa no/do cotidiano. Rio de Janeiro: DP\&A, 2001. (Coleção Metodologia e pesquisa do cotidiano).

NAJMANOVICH, Denise; DABAS, Elina (comp.). Redes el lenguaje de los vínculos. Hacia la reconstrucción y el fortalecimiento de la sociedad civil. Buenos Aires: Paidós, 1995. NICOLESCU, Basarab. Para uma educação transdisciplinar. In: LINHARES, Célia; TRINDADE, Maria Nazareth (Orgs.). Compartilhando o mundo com Paulo Freire. São Paulo: Cortez; Instituto Paulo Freire, 2003. p. 41-56.

SCHNITMAN, Dora Fried. Introdução: ciência, cultura e subjetividade. In: SCHNITMAN, Dora Fried (Org.). Novos paradigmas, cultura e subjetividade. Porto Alegre: Artes Médicas, 1996.

SOARES, Luiz Eduardo. A relação é o que (não) se vê. In: ATHAYDE, Celso; MV BILL; SOARES, Luiz Eduardo. Cabeça de porco. Rio de Janeiro: Objetiva, 2005. p. 172-173.

UNESCO. Declaração de Hamburgo sobre a Educação de Adultos e Plano de Ação para o Futuro. In: CONFERÊNCIA INTERNACIONAL SOBRE EDUCAÇÃO DE ADULTOS, 5., 1997, Hamburgo, Alemanha, 14-18 jul. 1997.
JANE PAIVA, doutora em educação pela Universidade Federal Fluminense (UFF), é professora da Faculdade de Educação da Universidade do Estado do Rio de Janeiro (UERJ), atuando na área de educação de jovens e adultos. Principais publicações: Concepção curricular para o ensino médio na modalidade de jovens e adultos: experiências como fundamento (In: FRIGOTTO, Gaudêncio; CIAVATTA, Maria (Orgs.). Ensino médio, ciência, cultura e trabalho. Brasília: MEC/SEMTEC, 2004. p. 207-235); Proposições curriculares na educação de jovens e adultos: emergências na formação continuada de professores baianos (In: OLIVEIRA, Inês Barbosa de (Org.). Alternativas emancipatórias em currículo. São Paulo: Cortez, 2004. p. 29-52); com IRELAND, Timothy; MACHADO, Maria Margarida (Orgs.). Educação de jovens e adultos: uma memória contemporânea - 1996-2004. Brasília: MEC; UNESCO, 2004); com OLIVEIRA, Inês Barbosa de (Orgs.). Educação de jovens e adultos. Rio de Janeiro: DP\&A, 2004); Literatura e neoleitores jovens e adultos: encontros possíveis no currículo? (In: PAIVA, Aparecida; MARTINS, Aracy; PAULINO, Graça; VERSIANI, Zélia (Orgs.). Literatura e letramento: espaços, suportes e interfaces; o jogo do livro (Belo Horizonte, Minas Gerais: Autêntica; CEALE/FaE/UFMG, 2003. p. 111-126); "Somos tantos Severinos..." producción de sentidos en la vida de brasileños no alfabetizados (In: MATUTE, Esmeralda (Coord.). Alfabetización y desarrollo: tres perspectivas para su estudio. Guadalajara, México: Universidade de Guadalajara, 2002. p. 71-89). Pesquisa em realização: "Concepções legais sobre a educação de jovens e adultos - estudo crítico sobre documentos dos Conselhos Estaduais de Educação". E-mail: janepaiva@terra.com.br

Recebido em agosto de 2006 Aprovado em outubro de 2006 


\section{Jane Paiva}

Tramando concepções e sentidos para redizer o direito à educação de jovens e adultos

Os programas e projetos na área da educação de jovens e adultos, na contemporaneidade, vêm revelando formas de compreender e apreender sentidos e necessidades dos variados públicos que os buscam, e intentando fazer cumprir, mais do que a perspectiva do aprender por toda a vida, o direito à educação sistematicamente negado a tantos na população brasileira. Com essa premissa inicial, a pesquisa explorou os modos como as propostas de atendimento de seis entidades - públicas, não-governamentais, de movimento social e do Sistema S (SESC, SESI, SENAR) têm enunciado as formulações na área e realizado práticas, visando a compreendê-las na história política nacional e internacional da educação de jovens e adultos, assim como as conexões, sentidos, nexos, articulações e imbricações que se produzem entre elas, para além dos limites das entidades, no complexo tecido social. $\mathrm{Na}$ perspectiva do direito, procurou-se penetrar nos diferentes níveis de realidade, possibilitando assim fazer emergir as produções subjacentes aos programas e projetos, com vista a cartografar a complexidade com que se fazem as práticas, e evidenciando elementos constituintes e instituidores de suas concepções.

Palavras-chave: educação de jovens e adultos; direito à educação; alfabetização

Plotting conceptions and meanings in order to re-express the right to adult and youth education

Current programmes and projects in the field of Adult and Youth Education reveal different ways of understanding and apprehending the meanings and needs of the varied publics who seek such programmes and of attempting to ensure less the perspective of lifelong learning and more the basic right to education systematically denied to so many Brazilians. Based on this initial premise, the research explores the different forms in which six organizations have formally stated their propositions as well as carried out their practical work in this field. Such organizations are characterized by being either public or nongovernmental, or pertaining to the social movement or to the S System (SESC, SESI, SENAR). The aim of this study is to comprehend such postulates and practices in the light of national and international policies of adult and youth education as well as the connections, meanings, nexus, articulations and overlapping which are produced between them and beyond the limits of these organizations in the complex social network. Within the perspective of rights, this investigation seeks to 
penetrate the different layers of reality in order to allow the productions subjacent to the programmes and projects to emerge with a view to mapping the complexity of those practices and reveal those elements which are constitutive and institutive of their conception.

Key words: adult and youth education, right to education, literacy

Tramando concepciones y sentidos para redecir el derecho a la educación de jóvenes y adultos

Los programas y proyectos en el área de la educación de jóvenes y adultos, en la contemporaneidad, vienen revelando formas de comprender y aprender sentidos y necesidades de los variados públicos que los buscan, $e$ intentando hacer cumplir, más de lo que la perspectiva del aprender por toda la vida, el derecho a la educación sistemáticamente negado a tantos en la población brasileña. Con esta premisa inicial, la pesquisa exploró los modos como las propuestas de atender a seis entidades - públicas, nogubernamentales, de movimiento social y del Sistema S (SESC, SESI,

SENAR) - han enunciado las formulaciones en el área y realizado prácticas, visando comprenderlas en la historia política nacional e internacional de la educación de jóvenes y adultos, así como las conexiones, sentidos, nexos, articulaciones e imbricaciones que se producen entre ellas, para más allá de los límites de las entidades, en la compleja trama social. En la perspectiva del derecho, se procuró penetrar en los diferentes niveles de realidad, posibilitando así hacer emerger las producciones subyacentes a los programas y proyectos, con vista a cartografiar la complejidad con que se hacen las prácticas, y evidenciando elementos constituyentes e instituidores de sus concepciones.

Palabras claves: educación de jóvenes y adultos; derecho a la educación;

alfabetización 